\title{
Study on Prevalence of Bovine Subclinical Mastitis and Associated Risk Factors in Smallholder Dairy Farms of Mecha District, West Gojam, Ethiopia
}

Yimam $\mathrm{TM}^{1}$, Kasse $\mathrm{GE}^{2 *}$ and Yitie $\mathrm{MT}^{3}$

University of Gondar, Department of Clinical Medicine, Ethiopia

*Corresponding author: Gashaw Enbiyale Kasse, University of Gondar, College of Veterinary Medicine and Science, Department of Clinical Medicine, P. O. Box. 196, Gondar, Ethiopia, Tel: +251921576312; Email: enbiyalegashaw@gmail.com

\section{Research Article}

Volume 4 Issue 5

Received Date: August 05, 2020

Published Date: September 29, 2020

DOI: $10.23880 /$ eij-16000161

\section{Abstract}

A cross sectional study was conducted in Mecha district, west Gojam, Ethiopia from December 2016 to March 2017 to estimate the prevalence of subclinical mastitis and to identify the role of some potential risk factors. A total of 344(225 local zebu and 119 local zebu crosses) lactating cows of smallholder farms were examined. The study was carried out through field screening surveys by the California Mastitis test for each quarter milk sample. The overall prevalence of subclinical mastitis was $21.8 \%$. Subclinical mastitis at cow level based on CMT was high (31.1\%) in crossbreds compared to indigenous zebu $(16.9 \%)(\mathrm{P}<$ 0.05). Overall prevalence at quarter level was $7.65 \%$ and quarter level subclinical mastitis prevalence based on CMT was $12.6 \%$ in crossbreds and $4.99 \%$ in local zebu breeds. Of the total1376 quarters examined 16 of them were blind. Among potential risk factors considered, breed and stage of lactation, were found to affect the occurrence of subclinical mastitis significantly $(\mathrm{p}<0.05)$ but age and parity were found insignificant for the occurrence of subclinical mastitis.

Ninety Farm owners were interviewed to assess their knowledge and practices towards subclinical and clinical mastitis. Among the interviewed farm owners 99.98 percent of them do not hear of subclinical mastitis but 78.9 percent of them heard about clinical mastitis. The majority of the participants $(81.1 \%, \mathrm{n}=73)$ used to wash their hands before and after milking with water but $18.9 \%(n=17)$ didn't wash their hands at all while milking the cow. Likewise $87.8 \%(n=79)$ of the participants responded that they didn't clean teats of the animal before or after milking. None of the interviewed farmers use towels and hand milking is a practice by all of the farmers. The prevalence of subclinical mastitis was high in the study area and thereby necessary measures are needed to be taken to prevent further losses.

Keywords: Subclinical Mastitis; Risk Factors; Clinical Mastitis

\section{Abbreviations: CMT: California Mastitis Test.}

\section{Introduction}

Ethiopia has the largest livestock population in Africa. The cattle population in the country is estimated to be 53.9 million, out of which female cattle constitutes about 55.4 percent. About $98.95 \%$ of the total cattle are local breeds and the remaining are hybrid and exotic breeds [1]. Although the country holds large potential for dairy development, the sector is not developed to the expected level. The annual growth rate in milk production of 1.2 percent falls behind the annual human population growth estimated at 3 percent. Milk consumption habit in the country is low with per capita consumption of $19 \mathrm{~kg}$ per year due to a multitude of factors [2]. 


\section{Epidemiology International Journal}

Diseases of the mammary glands known as mastitis are among the factors contributing to reduced milk production and consumption [3]. Mastitis is defined as an inflammatory reaction of the mammary gland induced when pathogenic microorganisms in the udder produce toxins that are harmful to the mammary gland [4]. It is primarily caused by a bacterial infection and is a major cause of economic loss in dairy cattle production [5]. As a result of the inflammation, milk composition is altered due to a decrease in the synthesis of caseins and lactose, and fat quantity and quality [6]. Mastitis also has negative effects on the quality of the milk and manufactured milk products, decreasing the shelf life of the liquid milk products [7].

Mastitis has two forms and clinical subclinical. Clinical mastitis is detected grossly by swelling redness, heat, and painful response and signs of systemic disturbances. Subclinical mastitis is more serious and is responsible for the much greater loss to the dairy industry [8]. It is 15 to 40 times more prevalent than the clinical form, is of long duration and difficult to detect $[9,10]$. It causes enormous losses for breeders and consequently influences the national income of a country [11]. Economic losses are due to loss in milk production, discarding abnormal milk and milk withheld from cows treated with antibiotics, degrading of milk quality and price due to high bacterial or somatic cell count, veterinary services and increased labor costs, increased risk of subsequent mastitis, herd replacement, and problems related to antibiotics residues in milk and its products [12].

In addition to economic impact, there is a danger that bacterial contamination of milk from affected cows may render it unsuitable for human consumption by causing food poisoning or in rare cases provide mechanisms of disease to humans. Tuberculosis and streptococcal sore throat may be spread in this way [13]. In Ethiopia the available information indicated that bovine mastitis is one of the most frequently encountered diseases of dairy cows. According to Lemma M, et al. [14] of the major diseases of crossbred cows in Addis, Ababa milk shed mastitis was the second most frequent disease next to reproductive diseases. The prevalence of clinical and sub clinical mastitis in Ethiopia range from 1.2 to $21.5 \%$ and 19 to $46.6 \%$, respectively [14-16]. However, most of these studies were carried out in Addis Ababa and its surroundings, capital of the country and fail to represent the occurrence of mastitis under different management and environmental situations in other regions of the country.

The study area Mecha district is a high potential cereallivestock site where dairy activities play a significant role in the livelihood of farmers in the area. The area has also better access to livestock development services and milk markets. Due to the above mentioned reasons and the economic capacity of the peasant's, small-holder dairy production with crossbred dairy cattle is a common practice in the area. Conversely, bovine mastitis was reported to be one of the most prevalent dairy health problems in most parts of Ethiopia where dairy activities are practiced. Yet, the information on the prevalence of sub clinical mastitis in the area is lacking and what available is fragments of information from cases of clinical mastitis that have been presented to the veterinary clinic for treatment.

Therefore this study was conducted with the following objectives:

- To estimate the prevalence of sub clinical mastitis

- To identify associated risk factors and asses owner's awareness about the disease.

\section{Materials and Methods}

\section{Study Area}

The study was conducted from November 2016 to April 2017 in Mecha district, west Gojam Ethiopia. The woreda is organized with 40 rural and 4 urban kebeles. The study area was selected purposively based on the availability of lactating cows. Mecha is one of the woredas in the Amhara Region of Ethiopia. The altitude of the woreda ranges from 1800 to $2,500 \mathrm{~m}$ above sea level. The mean annual rainfall ranges from $1000 \mathrm{~mm}$ to $2000 \mathrm{~mm}$. The mean temperature is between $24-27^{\circ} \mathrm{C}$. The study area is located at latitude $10^{\circ}$ $30^{\circ} \mathrm{N}$ and longitude $37^{\circ} 29^{\circ} \mathrm{E}$. Merawi is the capital for the woreda and is situated about 30 kilometers south of Bahir Dar, and approximately $525 \mathrm{~km}$ from Addis Ababa. Specifically, the town is located $7 \mathrm{~km}$ near to the Koga Dam. This woreda has a total population of 292,080 , of whom 147,611 are men and 144,469 women; 22,677 or $7.76 \%$ are urban inhabitants, with an area of 1,481.64 square kilometers. A total of 66,107 households were counted in this woreda, resulting in an average of 4.42 persons to a household, and 64,206 housing units. The majority of the inhabitants practiced Ethiopian Orthodox Christianity, with 98.91\% reporting that as their religion [17]. The land is covered by different vegetation types such as Savanna grassland, forest reverine and bush lands. Agriculture is the main economic sector in the area employing nearly $100 \%$ of the labor force. The main agricultural activities currently practiced include irrigation (modern and traditional) and mixed farming. The major agricultural products seasonally harvested include sorghum, maize, Teff, Wheat, linseed and other legume groups. In this Woreda there are 192, 556 cattle, 148, 971 ovine, 23, 106 equine and 204,181 poultry.

\section{Study Animal Population}

The study animals in this study were indigenous zebu and crossbred lactating cows in small holder farms. The average 


\section{Epidemiology International Journal}

herd size was 2.29 with a maximum of 13 cows. One hundred fifty households were included and most of them use family labor. All of them used hand milking and both intensive and semi-intensive type of management was practiced. The major feed resources used were maize bran, wheat bran, by products from the traditional alcoholic beverages (especially those small holder farms in Merawi), grazing, and other crop residues were also among the dominant feed items in this small holder system. Housing was a concrete floor with a shed and wooden wall in most households.

\section{Selection of the Study Animals}

Apparently healthy animals were considered in the study. Those with clinical mastitis were excluded.

\section{Study Design}

A cross-sectional study was conducted in Mecha district On 344 cows(121 cross and 223 local zebu breeds) from December 2016 to April 2017 to estimate the Prevalence of subclinical mastitis and to identify the associated risk factors at cow level based on an indirect test (California Mastitis Test, CMT).

2.5. Sample Size Determination and Sampling Strategy

The sample size was determined at a $95 \%$ confidence interval, $5 \%$ precision and expected prevalence $34.4 \%$ from previous studies [9] and found to be 344 animals. The household's lists were recorded and were taken as a sampling frame. Simple random sampling was considered to select the study households. All lactating cows in the selected household were included in the study. Prevalence was calculated according to the formula given in Thrusfield $\mathrm{M}[18]$.

$$
N=\frac{(1.96) 2 \times P \exp (1-P \exp )}{d^{2}}
$$

Where, $\mathrm{N}=$ number of sample size, $\mathrm{p}$ exp =expected prevalence, $\mathrm{d}=$ Absolute precision

Therefore, based on the mentioned formula 344 animals were considered in the study.

\section{Sample Collection and CMT Test}

The udders and especially teats were cleaned and dried before sample collection. Each teat end was scrubbed with cotton moistened with $70 \%$ ethyl alcohol. A squirt of milk, about $2 \mathrm{ml}$ from each quarter was placed in each of four shallow cups in CMT paddle after removing the first droppings. And then an equal amount of the CMT reagent was added to each cup. A gentle circular motion was applied to the mixtures in a horizontal plane for 15 seconds. A cow or a quarter was considered to have subclinical mastitis if CMT score is 1, 2 or 3 and the California Mastitis Test (CMT) will be carried out according to the method described by Quinn PJ, et al. [19].

\section{Questionnaire Survey}

A semi structured pretested questionnaire was developed and all information relating to the study objectives was recorded. Data were collected on potential risk factors for the occurrence of subclinical mastitis in dairy cows based on observation and by interviewing the farm owners or handlers. The animal level factors such as herd size, teat blindness, parity, lactation stage, breed, and age difference were recorded. Barn floor status, type of milking method, use of towels, milking sequences and hygiene was also recorded.

\section{Data Management and Statistical Analysis}

The collected data were recorded in the format developed for this purpose and later on entered into the Microsoft excel 2007 program and analyzed using SPSS version 20 software. Descriptive statistics were used to understand the nature and the characteristics of the data. A Ch-square test was employed to see if there was a significant difference between CMT results and the risk factors. To this end, a statistically significant association between variables was considered to exist if the computed p-value was less than 0.05 .

\section{Results}

\section{California Mastitis Test Result}

Overall and Quarter Prevalence of Subclinical Mastitis: A total of 344 cross-bred and local zebu breed cows were examined for subclinical mastitis detection and out of which $75(21.8 \%)$ of the cows were found to be affected with sub clinical mastitis based on CMT result. Out of the total 1376 quarter examined $16(1.16 \%)$ quarters were found to be blind teat. As indicated in (Tables 1-6), up on screening of the functional teats (1360) by CMT, a quarter of $104(7.65 \%)$ found to be affected by sub clinical mastitis. Quarter level subclinical mastitis prevalence based on CMT was $12.6 \%$ in crossbreds and $4.99 \%$ in local zebu breeds.

\begin{tabular}{|c|c|c|c|}
\hline Quarter & $\begin{array}{c}\text { No. } \\
\text { examined }\end{array}$ & Positive & $\begin{array}{c}\text { Prevalence } \\
\text { (\%) }\end{array}$ \\
\hline LF & 342 & 21 & 6.14 \\
\hline RF & 342 & 32 & 9.35 \\
\hline LH & 334 & 31 & 9.28 \\
\hline RH & 342 & 20 & 5.84 \\
\hline Total & 1360 & 104 & 7.65 \\
\hline
\end{tabular}

Table 1: Quarter prevalence of sub clinical mastitis using the California Mastitis Test $(\mathrm{n}=1360)$. 


\section{Epidemiology International Journal}

\begin{tabular}{|c|c|c|c|}
\hline Quarters & Total No. examined & No of blind teats & Prevalence \\
\hline Left fore & 344 & 2 & 0.58 \\
\hline Right fore & 344 & 2 & 0.58 \\
\hline Left hind & 344 & 10 & 2.91 \\
\hline Right hind & 344 & 2 & 0.58 \\
\hline Total & 1376 & 16 & 1.16 \\
\hline
\end{tabular}

Table 2: Quarter level blind teats distribution $(n=344)$.

\begin{tabular}{|c|c|c|c|c|c|}
\hline Breed type & Total examined & No. positive & Prevalence (\%) & P value & $\mathbf{X}^{2}$ value \\
\hline cross & 119 & 37 & 31.1 & \multirow{2}{*}{0.002} & 9.21 \\
\hline local & 225 & 38 & 16.9 & & \\
\hline Total & 344 & 75 & 21.8 & & \\
\hline
\end{tabular}

Table 3: Prevalence of subclinical mastitis with respect to breed $(n=344)$.

\begin{tabular}{|c|c|c|c|c|c|}
\hline Parity group & Total cows examined & No. positive & Prevalence (\%) & P value & $\mathbf{X}^{2}$ value \\
\hline 2-Jan & 174 & 39 & 22.4 & & \\
\cline { 1 - 4 } 5-Mar & 160 & 32 & 20 & 0.319 & 2.29 \\
\hline$>5$ & 10 & 4 & 40 & & \\
\hline Total & 344 & 75 & 21.8 & & \\
\hline
\end{tabular}

Table 4: Prevalence of subclinical mastitis with respect to parity number $(n=344)$.

\begin{tabular}{|c|c|c|c|c|c|}
\hline Age group & Total examined & No. positive & Prevalence (\%) & P value & $\mathbf{X}^{2}$ value \\
\hline 2-4 years & 39 & 9 & 23.1 & & \\
\hline 5-8 years & 171 & 37 & 21.6 & 0.98 & 0.42 \\
\hline Above 8 years & 134 & 29 & 21.6 & & \\
\hline Total & 344 & 75 & 21.8 & & \\
\hline
\end{tabular}

Table 5: Prevalence of subclinical mastitis with respect to age $(n=344)$.

\begin{tabular}{|c|c|c|c|c|c|}
\hline Stage of lactation & Total cows examined & No. Positive & Prevalence (\%) & P value & $\mathbf{X}^{2}$ value \\
\hline Early lactation $(<4$ month) & 178 & 53 & 29.8 & & \multirow{2}{*}{0.001} \\
\cline { 1 - 4 } Mid lactation (4-6 month) & 112 & 16 & 14.29 & 13.97 \\
\cline { 1 - 4 } Late lactation $>6$ months & 54 & 6 & 21.8 & & \\
\hline Total & 344 & 75 & & \\
\hline
\end{tabular}

Table 6: Prevalence of subclinical mastitis with respect to lactation length $(n=344)$.

Prevalence of Subclinical Mastitis with Respect To Different Risk Factors: The occurrence of sub clinical mastitis was more likely in cross breeds compared to local zebu breeds and the difference was statistically significant $(p<0.05)$. There was no significance difference among age groups for the occurrence of subclinical mastitis. In the stage of lactation the prevalence of subclinical mastitis was high at the early stage of lactation; than the mid and late stage of lactation. Subclinical mastitis prevalence was high in parity groups $>5$ calves but the difference was statistically insignificant $(\mathrm{p}>0.05)$.

Questionnaire Survey Result: To assess knowledge and practices implemented by the cattle owners in the study area, a total of 90 participants were interviewed using a pre tested, semi structured questioner. Among the participants $64.5 \%(\mathrm{n}=58)$ have semi intensive farms while $35.5 \%(\mathrm{n}=32)$ have intensive farms and the majority $(67.8 \%, \mathrm{n}=61)$ have 


\section{Epidemiology International Journal}

local breed cows with a maximum of 5 cattle. Out of the total participants $78.9 \%(n=71)$ heard about clinical mastitis and all respondents able to identify major symptoms of clinical signs in case of clinical mastitis though nearly all of them $(98.9 \%, \mathrm{n}=89)$ have no idea about subclinical mastitis. Of the total interviewed farmers $70(77.8 \%)$ of them control clinical mastitis by treatment and the rest $20(22.2 \%)$ doing nothing. None of them use intramamary antibiotics for heifers and dry cows. None of them $100 \%(n=90)$ use intramamary antibiotics for heifers and dry cows.

\begin{tabular}{|c|c|c|c|}
\hline Variable & Owners' response & Frequency & Percent \\
\hline \multirow{3}{*}{ Farm management system } & Intensive & 32 & 35.5 \\
\hline & Semi intensive & 58 & 64.5 \\
\hline & Extensive & 0 & 0 \\
\hline \multirow{2}{*}{ Owned number of cows } & 5-Jan & 81 & 90 \\
\hline & 13-Jun & 9 & 10 \\
\hline \multirow{3}{*}{ Type of breeds kept } & Local & 61 & 67.8 \\
\hline & Cross & 24 & 26.7 \\
\hline & Both & 5 & 5.6 \\
\hline \multirow{4}{*}{ Hand washing practice during milking } & Before milking only & 0 & 0 \\
\hline & After milking only & 0 & 0 \\
\hline & Before and after milking & 73 & 81.1 \\
\hline & Not at all & 17 & 18.9 \\
\hline \multirow{3}{*}{ Materials used to wash hands } & Rinse with water only & 90 & 100 \\
\hline & Use water with soap & 0 & 0 \\
\hline & Use special disinfectants & 0 & 0 \\
\hline \multirow{4}{*}{ Teat cleaning practice during milking } & Before milking only & 11 & 12.2 \\
\hline & After milking only & 0 & 0 \\
\hline & Both before and after milking & 0 & 0 \\
\hline & No cleaning & 79 & 87.8 \\
\hline \multirow{2}{*}{ Heard of clinical mastitis } & Yes & 71 & 78.9 \\
\hline & No & 19 & 21.1 \\
\hline \multirow{2}{*}{ Heard of subclinical mastitis } & Yes & 1 & 1.1 \\
\hline & No & 89 & 98.9 \\
\hline \multirow{2}{*}{ Check their cow for subclinical mastitis } & Yes & 1 & 1.1 \\
\hline & No & 89 & 98.9 \\
\hline \multirow{2}{*}{ Had mastitis case in their heard } & Yes & 58 & 64.5 \\
\hline & No & 32 & 35.5 \\
\hline \multicolumn{4}{|l|}{ Appreciate symptoms of clinical mastitis: } \\
\hline \multirow{2}{*}{ - Clots or flakes in the milk } & Yes & 90 & 100 \\
\hline & No & 0 & 0 \\
\hline \multirow{2}{*}{ - Swollen teats } & Yes & 90 & 100 \\
\hline & No & 0 & 0 \\
\hline \multirow{2}{*}{ • Hot and swollen udder } & Yes & 90 & 100 \\
\hline & No & 0 & 0 \\
\hline \multirow{2}{*}{ - Decreased milk production } & Yes & 90 & 100 \\
\hline & No & 0 & 0 \\
\hline
\end{tabular}

Table 7: Cattle owner's knowledge and practices towards clinical and subclinical mastitis. 


\section{Epidemiology International Journal}

Though the majority of the participants $(81.1 \%, \mathrm{n}=73)$ used to wash their hands before and after milking their animal, none of them uses any detergent or disinfectants and even $18.9 \%(n=17)$ didn't wash their hands at all while milking the cow. Likewise $87.8 \%(n=79)$ of the participants responded that they didn't clean teats of the animal before or after milking. None of the farmers use towels and glove during milking (Table 7). None of the farmers $100 \%(n=90)$ use a towel and glove during milking.

\section{Discussion}

The overall prevalence of subclinical mastitis found in this study $(21.8 \%)$ was lower than the finding of (Bedada et al.) who reported $55.8 \%$ prevalence. However, a lower prevalence of up to $14.8 \%[20,21]$ and prevalence as high as $62.9 \%-95 \%$ has been reported. This overall prevalence of subclinical mastitis in the present study (21.8\%) was relatively lower than previous studies in Ethiopia, Bishi AS [22], Workineh S, et al. [15] and Almaw G, et al. [9] reported $34.30,38.2$ and $34.4 \%$, respectively. However, the prevalence of subclinical mastitis in this study is relatively higher than in previous studies $(9.81 \%)$ in Southern Ethiopia. The result in this study (21.8\%) was comparable with Almaw G, et al. [23] in Gondar and Biffa D, et al. [3] in Khartoum, who had reported $25.22 \%$ and $23 \%$ prevalence respectively.

Quarter prevalence of subclinical mastitis 7.65\% found in this study was lower than the finding of Zeryehun $\mathrm{T}$, et al. who reported a quarter prevalence rates of $42.7 \%$. This quarter prevalence is also lower than the report made by Bachaya HA, et al. [24] in Pakistan, Zelalem G [25] in Ethiopia, Fadlelmoula A, et al. [26] in Germany, who reported 35.25\%, $15.92 \%$, and $27.57 \%$, respectively. As compared to the others the left hind quarters were blind with the highest rate $(2.91 \%)$ than other quarters. This might be due to the high production capacity of the hind quarters and the high chance of getting fecal and environmental contamination which might contribute to the formation of fibrosis and closure of the teat orifice.

The prevalence of subclinical mastitis in crossbreds at cow level based on CMT in the present study (31.1\%) was comparable to the finding of Almaw G, et al. [9] who reported $34.4 \%$ prevalence in and around Bahirdar but lower than to a study carried out in Tanzania which was found to be as high as $90.3 \%$. The prevalence of subclinical mastitis at cow level found in this study (16.9\%) for local breeds was also comparable with Almaw G, et al. [9] who reported $17.9 \%$ prevalence. As mastitis is a complex disease involving interactions of various factors such as husbandry, environmental conditions, animal risk factors, and causative agents, its prevalence will vary.
Among the risk factors considered the occurrence of subclinical mastitis was higher in crossbreds (31.1\%) compared to local zebu (16.9\%) and the difference was statistically significant $(\mathrm{p}<0.05)$.This is inconsistent with the study conducted by Almaw G, et al. [9]. The high prevalence of subclinical mastitis in cross breeds could be due to the high production capacity as compared with the local breeds.

In this study Prevalence of subclinical mastitis was affected significantly with the lactation stage. The early lactation stage had a higher relative prevalence (29.8\%) than mid (14.29\%) and late (11.11\%) lactation stage. This result was in close alignment with reports by Delelesses GD [27], Moges N, et al. [28]; Zeryhun T, et al. [29]. The high prevalence at an early age could be due to the absence of a dry cow therapy regime and early infection associated with delayed diapedesis of neutrophils in to the mammary gland. In the present study, there was no significant difference between age groups for the occurrence subclinical mastitis, which is in contrary with other studies by Moges N, et al. [28], Zeryhun T, et al. [29], who had reported mastitis was higher in adult cows $(93.2 \%)$ than young adults $(65 \%)$. The result of this study might be due to the importance of other factors such as husbandry, environmental conditions, and causative agents than the difference in age.

In the present study cows with many calves were greater at risk than those of cows having moderate and few calves. A similar finding was reported by Moges, et al. Radostitis et al. have explained that cows with more parity numbers have the largest teats and more relaxed sphincter muscles, which increase the accessibility of infectious agents in the cows' udder.

In Ethiopia, the subclinical form of mastitis received little attention, and efforts have been concentrated on the treatment of clinical cases Hussein N, et al. [30], Mungube E0, et al. [31] reported that losses associated with subclinical mastitis in crossbred dairy cows in the central highlands of Ethiopia were found to be US\$38 for each cow per lactation. Usually Ethiopian farmers especially Smallholders are not well informed about the invisible loss from subclinical mastitis [32] and were also true in Tanzanian and Ugandan farmers.

In this study, all most all of the farmers interviewed did not know and screened their cows for subclinical mastitis except seeking veterinarian assistance at times of clinical cases. Extensions packages that increase farmers' awareness of subclinical mastitis would be helpful in mastitis control in the area and improve farmers' income. The present study concluded that subclinical mastitis was a major health problem of dairy cows in the area and undoubtedly will have 


\section{Epidemiology International Journal}

an adverse effect on the productivity of the dairy industry and hence needs serious attention. Good record keeping practice on the general herd health of dairy farms, adequate housing with proper sanitation and ventilation should be regularly maintained. Correct and good milking techniques are essential in prevention strategies. Furthermore, regular screening for the detection of subclinical mastitis and proper treatment of the clinical cases as well as appropriate treatment of cows during the dry and lactation period should be practiced [33].

\section{Conclusion and Recommendations}

Though large research efforts aimed to gain prevalence and to develop new control tools for mastitis, the subclinical occurrence of mastitis remains a substantial problem for dairy producers. The result of the present study indicated that high prevalence of subclinical mastitis in dairy cattle of the study area and this could be due to poor milking hygiene, contagious nature of pathogens and absence of dry cow therapy, lack of strategic control measures against the disease, as well as poor surveillance measures, lack of maintenance of strict hygiene and good sanitary environment [34].

Therefore, based on the above conclusion the following recommendations have forwarded;

- Farmers should ensure strict personal hygiene and that of animals, and the general sanitary condition of the farms should be improved and maintained.

- Screening of cows and milk for subclinical and clinical mastitis.

- Dry cow therapy should be practiced.

- Extension services and training programs aiming at the creation of awareness about the importance and prevention of subclinical mastitis among smallholder dairy farmers should be practiced.

- Milking infected animals and their respective quarters at last and periodic monitoring of infection status of the udder.

- For early detection of subclinical mastitis CMT can be performed on a regular basis as a control measure.

- By identifying the causal agent, the best antibiotic could be used to counter a specific bacterium species.

\section{Declaration}

We, the under signed declare that the information presented here in our thesis is our original work, has not been presented for a degree in any other University and all that sources of material used for the thesis have been duly acknowledged.

\section{References}

1. CSA (2013) Agricultural Sample Survey 2012/13 [2005] Volume II. Report On Livestock and Livestock Characteristics (Private Peasant Holdings) Federal Democratic Republic of Ethiopia Central Statistical Agency (CSA).

2. FAO (2003) Livestock Sector Brief.

3. Biffa D, Etana D, Fekadu B (2005) Prevalence and risk factors of mastitis in lactating dairy cows in southern Ethiopia. Intern J Appl Res Vet Med 3(3): 189-198.

4. Fratini F, Casella S, Leonardi M, Pisseri F, Ebani VV, et al. (2014) Antibacterial activity of essential oils, their blends and mixtures of their main constituents against some strains supporting livestock mastitis. Fitoterapia 96: 1-7.

5. Hosseinzadeh S, Saei HD (2014) Staphylococcal species associated with bovine mastitis in the North West of Iran: Emerging of coagulase-negative staphylococci. International Journal of Veterinary Science and Medicine 2(1): 27-34.

6. Botaro BG, Cortinhas CS, Dibbern AG, Silva LFP, Benites NR, et al. (2015) Staphylococcus aureus intramammary infection affects milk yield and SCC of dairy cows. Trop Anim Health Prod 47(1): 61-66.

7. Guerin-Faublee V, Tardy F, Bouveron C, Carret G (2002) Antimicrobial susceptibility of Streptococcus species isolated from clinical mastitis in dairy cows. Int J Antimicrob Agents 19(3): 219-226.

8. Kader MA, Samad MA, Saha S (2003) Influence of host level factors on prevalence and economics of subclinical mastitis in dairy cows in Bangladesh. Indian Journal of Dairy Science 56: 235-240.

9. Almaw G, Zerihun A, Asfaw Y (2008) Bovine mastitis and its association with selected risk factors in smallholder dairy farms in and around Bahir Dar, Ethiopia. Trop Anim Health Prod 40(6): 427-432.

10. Sarker SC, Parvin MS, Rahman AKMA, Islam MT (2013) Prevalence and risk factors of Subclinical Mastitis in Lactating dairy cows in north and south region of Bangladesh. Trop Anim Health Prod 45(5): 1171-1176.

11. McDougall S, Parker KI, Heuer C, Compton CWR (2009) Compton A review of prevention and control of heifer mastitis vianon-antibiotic strategies. Vet Microbiol 134(1-2): 177-185.

12. Getahun K, Kelay B, Bekena M, Lobago F (2008) Bovine mastitis and antibiotic resistance pattern in sellale 
smallholder dairy farms, Ethiopia. Trop Anim Health Product 40(4): 216-268.

13. Radostits DR, Blood DC (1994) veterinary medicine. A text book of the disease of Cattle, Sheep, Goats and Horses. $8^{\text {th }}$ (Edn.), Bailler Tindall, London, pp: 563-564.

14. Lemma M, Kassa T, Tegegene A (2001) Clinically manifested major health problems of crossbred dairy herds in urban and periurban production systems in the central high lands of Ethiopia. Trop Anim Health Prod 33(2): 85-89.

15. Workineh S, Bayleyegne M, Mekonnen H, Potgieter LND (2002) Prevalence and etiology of mastitis in cows from two major Ethiopian dairies. Trop Anim Health Prod 34(1): 19-25.

16. Kerro 0, Tareke F (2003) Bovine mastitis in selected areas of Southern Ethiopia. Trop Anim Health Prod 35(3): 197-205.

17. CSA (2007) National census conducted by the Central Statistical Agency of Ethiopia.

18. Thrusfield $M$ (2005) Veterinary Epidemiology. $2^{\text {nd }}$ (Edn.), Black well science Ltd, London, pp: 182-198.

19. Quinn PJ, Carter ME, Markey B, Carter GR (1999) Clinical Veterinary Microbiology. Harcourt Publishers Ltd, London.

20. Enyew GA (2004) A cross-sectional study of bovine mastitis in and around bahirdar and antibiotic resistance patterns of major pathogens. MSc thesis, Addis Ababa University Debre, Zeit, Ethiopia.

21. Sori H, Zerihun A, Abdicho S (2005) Dairy cattle mastitis in and around Sebeta, Ethiopia. Intern J Appl Res Vet Med 3(4): 332-338.

22. Bishi AS (1998) Cross-sectional and longitudinal prospective study of bovine clinical and subclinical mastitis in periurban and urban dairy production systems in the Addis Ababa region, Ethiopia, MSc Thesis, Faculty of Veterinary Medicine, Addis Ababa University School of Graduate Studies and Freie Universitat, Berlin, Berlin.

23. Almaw G, Molla W, Melaku A (2009) Prevalence of bovine subclinical mastitis in Gondar town and surrounding areas, Ethiopia. Livestock Research for Rural Development 21(7).

24. Bachaya HA, Raza MA, Murtaza S, Akbar IUR (2011) Subclinical bovine mastitis in Muzaffar Garh district of Punjab (Pakistan). The J Anim Plant Sci 21(1): 16-19.

25. Zelalem G (2001) Prevalence of mastitis and

\section{Epidemiology International Journal}

identification of major isolates in Walaita Sodo. DVM Thesis, Jimma University, Ethiopia.

26. Fadlelmoula A, Fahr RD, Anacker G, Swalve HH (2007) The Management Practices Associated with Prevalence and Risk Factors of Mastitis in Large Scale Dairy Farms in Thuringia-Germany 1: Environmental Factors Associated with Prevalence of mastitis. Aust J Basic and Applied Sci 1(4): 619-624.

27. Delelesse GD (2010) Study on prevalence of bovine mastitis on Cross breed dairy cow around Holeta areas, West Shoa Zone of Oromia, Ethiopia. Global Vet 5(6): 318-323.

28. Moges N, Asfaw Y, Belihu K (2011) A Cross Sectional Study on the Prevalence of SubClinical Mastitis and Associated Risk Factors in and around Gondar, Northern Ethiopia. Int J Ani Vet Adv 3(6): 455-459.

29. Zerihun T, Aya T, Bayecha R (2013) Study on prevalence of bacterial pathogens and associated risk factors of bovine mastitis in small holder dairy farms in and around Addis Ababa Ethiopia. The Journal of Animal and Plant Sciences 23(1): 50-55.

30. Hussein N, Yehualashet T, Tilahun G (1997) Prevalence of mastitis in different local and exotic breeds of milking cows. Ethiopian Journal of Agricultural Science 16: 5360.

31. Mungube EO, Tenghagen BA, Regassa F, Kyule MN, Shiferaw Y, et al. (2005) Reduced milk production in udder quarters with subclinical mastitis and associated economic losses in crossbred dairy cows in Ethiopia. Trop Anim Health Prod 37(6): 503-512.

32. Hussein N (1999) Cross sectional and longitudinal study of bovine mastitis in urban and peri urban dairy systems in the Addis Ababa region, Ethiopia, MSc Thesis, Faculty of Veterinary Medicine, Addis Ababa University School of Graduate Studies and Freie University, Berlin, Berlin.

33. Adane B, Guyo K, Tekle Y, Taddele H, Bogale A, et al. (2011) Study on Prevalence and Risk Factors of Bovine Mastitis in Borana Pastoral and Agro-Pastoral Settings of Yabello District, Borana Zone, Southern Ethiopia. American Eurasian J Agric Environ Sci 12(10): 12741281.

34. Radostits OM, Gay C, Blood DC, Hinchcliff K, Constabl $P$ (2007) Mastitis. Veterinary Medicine: A Text book of disease of cattle, sheep, pigs, goats, and horses. $10^{\text {th }}$ (Edn.), W.B. Saunders Company Ltd, Ballier, Tindall, London, pp: 674-762.

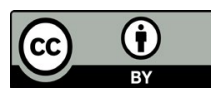

